\title{
Isolation and Characterization of Bacterial Agents Associated of Wetwood Disease on EIm Trees in Iran
}

\author{
M. ALIZADEH*, R. KHAKVAR and A. BABAI-AHARI \\ Plant Protection Department, Faculty of Agriculture, University of Tabriz, Tabriz, Iran
}

(Received: 19 March 2017; accepted: 22 June 2017)

\begin{abstract}
Elm trees (Ulmus spp.) are one of the most widespread landscape plants, widely used as ornamental trees to embellish parks and streets of different countries including Iran. Elm trees cultivation is seriously limited by biotic factors such as bacterial pathogens. Recently, bacterial wetwood has been identified as a common disease on elm trees in Northwest Iran. In present study, in order to identify bacterial pathogens associated with elm trees, wetwood infected samples were collected from elm trees showing wetwood symptom across Tabriz city and immediately transferred to the lab. After isolation and purification of isolates, hypersensitive reaction (HR), pathogenicity, biochemical and molecular tests were used to characterize the isolates. In total of 92 isolates obtained, 32 and 10 isolates were able to induce HR and wetwood symptoms on tobacco leaves and young branches of elm, respectively. Based on biochemical and molecular tests, the identity of the isolates studied were determined as Brevundimonas bullata, Paracoccus alcaliphilus, P. marcusii and Luteimonas aestuarii. To the best of our knowledge, this study shows that these four bacterial species here reported are responsible for the causal agent-complex of wetwood disease on elm trees for the first time in the world.
\end{abstract}

Keywords: Elm, wetwood, bacterial pathogens, molecular identification, East Azarbaijan.

Elm (Ulmus spp.) is a deciduous and semi-deciduous tree that belongs to the U1maceae family. These trees are well-known ornamental plants and because of having unique properties such as resistance to extreme conditions, fast growth in different soils and appropriate physiological factors (suitable height and foliage shape) has extensively been spreaded into other habitats and countries worldwide including Iran (Iraqi et al., 2008). These trees embellish the avenues and gardens of Europe, North America and China and they are traditionally utilized by human for food, medicine, fibre, fodder for cattle, timber for construction, firewood and a living support for grapevine (Santini et al., 2002). There is no accurate information regarding elm trees density all over the world, although it is estimated that there are 136 million elm trees worldwide which are mainly found in Europe, Asia and North America (Stipes and Campana, 1981). In Iran, there is no information available on elm trees density as well, but five species of elm trees including $U$. compestris, U. glabra, U. minor, U. chinensis and $U$. umbraculifera are frequently grown in different areas (Iraqi et al., 2008). Over the past years, various biotic factors

* Corresponding author; e-mail: Mehrdad.alizadeh14@yahoo.com 
including plant diseases such as Dutch elm (Ophiostoma novo-ulmi), black leaf spot (Stegophora ulmea), Botryodiplodia canker (Botryodiplodia sp.), leaf scorch (Xylella fastidiosa), elm yellows (Phytoplasma) and wetwood (bacterial pathogens) were involved in major losses of elm trees (Stipes and Campana, 1981). Compared to other plant diseases, bacterial wetwood or slime flux is a common disease that besides elm trees negatively affects the central core of many shade, ornamental and forest trees such as ash, fir, maple, oak and sycamore (Scortichini et al., 1991). Although wetwood is of no importance compared to the lethal dutch elm disease, wetwood is the most serious in the forest industry where lumber from afflicted trees is discolored (Roberts, 2011).

Wetwood disease results when bacterial pathogens invade through wounds and grow in branches and trunks. Wetwood is a water-soaked or soaking condition of wood and bark in the branches, trunks (stems) and roots of trees (Carter, 1945). So for creating water-soaked condition by bacteria, water is moved from host intracellular into intercellular spaces. Furthermore, the exuding liquid (ooze) is forced from infected tissues through wounds (created by lawn mowers, pruning tools, insects, ice and wind) by gas production caused by bacterial fermentation activity in the affected tissues of wetwood and these oozes remain as streaks of dried effluent on bark surface (Murdoch and Campana, 1983). Generally, the occurrence of wetwood in the central core of senescent xylem belonging to large stems is regarded as nonpathological while in younger stem with responsive outer sapwood as pathological (Murdoch and Campana, 1983). This disease was initially studied by Carter (1945) and Lelliottia nimipressuralis (formely known as Erwinia nimipressuralis and then reclassified to Enterobacter nimipressuralis) was described as the sole causative agent of the disease. However, more detailed research showed that several bacterial species were isolated from infected tissues and were named as associated bacteria with wetwood (Murdoch and Campana, 1983). In Iran, wetwood disease has recently been studied in Rafsanjan city on elm trees and L. nimipressuralis reported as associated bacteria with wetwood disease (Khodaygan et al., 2011).

In recent years, wetwood disease has become a common disease on elm trees in Tabriz city in Iran where elm trees have high density compared to other shade trees in the parks and streets. Therefore, the present study aimed to isolate potential bacterial agents associated with elm wetwood disease observed on elm trees and characterize them using pathogenicity test and biochemical and molecular examinations.

\section{Materials and Methods}

\section{Sampling and isolation}

During sampling process, the branches and trunk bark of elm trees showing wetwood symptoms were collected over the gardens, parks and streets in Tabriz city in Iran (East Azarbaijan province). Infected samples (10-30 $\mathrm{cm}$ in diameter) were taken from upper part of elm trees at 2 to 4 meters above mean ground level. For isolation, the bark 
surrounding the wetwood was initially removed with sterile scalpel and small segments (10 to $15 \mathrm{~mm}$ square) were then made from the margins and centers of the browned parts. The segments were sterilized in $70 \%$ alcohol for 30 seconds and rinsed three times in sterilized distilled water for 10 seconds. Smaller pieces were then made and placed into sterilized distilled water for one hour to release bacteria. Suspension obtained were streaked onto nutrient agar (NA) medium and incubated for three days in $27^{\circ} \mathrm{C}$ in darkness (Roos and Hatting, 1986). After the growth of the colonies was observed, single colonies were then taken and purified. All colonies purified were preserved in sterile distilled water in $4{ }^{\circ} \mathrm{C}$ for further investigations.

\section{Hypersensitive reaction}

All isolates obtained in this study were inoculated on tobacco leaves to assess hypersensitive reaction (HR) induction (Thomidis et al., 2005). Initially, two-day-old colonies developed on NA medium were used to prepare a bacterial suspension at concentration of $1 \times 10^{7} \mathrm{CFU} / \mathrm{ml}$ from each isolate. Twenty $\mu$ of each bacterial suspension was injected between upper and lower epidermis tissue using sterile insulin syringe. For control, sterile distilled water was injected instead of bacterial suspension. The rapid death of plant cells or necrotic symptoms in injections sites after 24 to 48 were considered as HR occurrence (Thomidis et al., 2005).

\section{Pathogenicity test}

To satisfy Koch's postulate, 32 bacterial isolates selected based on HR reaction were inoculated on elm young branches $2 \mathrm{~cm}$ in diameter and $25 \mathrm{~cm}$ in length which were excised from elm trees. The pathogenicity test was conducted according to the method described by Moretti et al. (2007) with some changes. Initially, both sides of scions were covered with humid cotton to keep humidity until sprouting and each scion was then sterilized using 70\% ethanol. On surface of branches a single incision into the branch $2 \mathrm{~cm}$ long was made using sterile scalpel and inoculated with single bacterial suspension of isolates (as separately with a single bacterium of each isolate) selected at concentration of $1 \times 10^{7} \mathrm{CFU} / \mathrm{ml}$. Inoculation sites were firmly covered using parafilm and all inoculated branches were kept in humid condition for 30 days. In order to control, sterile distilled water was injected instead of bacterial suspension. Then, parafilms were removed and all inoculated branches were further maintained in temperature at $5{ }^{\circ} \mathrm{C}$ for 10 days. The pathogenicity of these isolates was confirmed after the observation of wetwood symptoms on inoculation sites that these symptoms are included wetting or soaking of bark (water-soaked areas) in young branches. In natural condition and in robust and old trees, this is expected that wetwood symptoms is accompanied with wetting and soaking of bark and ooze production (Murdoch and Campana, 1983); but because of lacking ooze production in young branches in laboratory condition, wetting or soaking of bark (water-soaked areas) is sufficient as wetwood symptom for pathogenicity test. 


\section{Biochemical tests}

Different biochemical tests including catalase, oxidase, Gram $(\mathrm{KOH})$, citrate, lactose, maltose, D-mannitol and sucrose (Schaad, 2001) were used to characterize bacterial isolates selected.

\section{DNA extraction and polymerase chain reaction assays}

In order to conduct DNA extraction, a loop of one-day-old culture of each selected bacterial isolate was added to $1.5 \mathrm{ml}$ tubes containing 500 micro liters TBA buffer and shooked well to make a homogeneous bacterial suspension. Then, $5 \mu \mathrm{fpt} 10 \% \mathrm{KHO} 10 \%$ was added to each tube for lysing bacterial cells better and placed into boiling water for $10 \mathrm{~min}$. In next stage, all tubes were centrifuged in $12000 \mathrm{rpm}$ for $4 \mathrm{~min}$ and upper phase containing DNA were transferred to new tubes containing deionized water and maintained at $-20{ }^{\circ} \mathrm{C}$ for further examinations (Arabi et al., 2006). In PCR assay, the primer sets of 27F (5'-TCCGTAGGTGAACCTGCGG-3') and 1492R (5'-TTCTCCGCTTATTGATATGC-3') were used to amplify 16s rDNA region (Weisburg et al., 1991). The PCR reaction was performed in a total volume of $12.5 \mu \mathrm{l}$. The PCR mixture contained $10 \mathrm{ng}$ genomic DNA, $6.2 \mu \mathrm{l}$ Master Mix (CinnaGen, Iran) and $0.2 \mu \mathrm{M}$ of each primer. Thermal cycles were adjusted as initial denaturation at $95^{\circ} \mathrm{C}$ for $5 \mathrm{~min}$, followed by 36 cycles of $60 \mathrm{~s}$ at $94{ }^{\circ} \mathrm{C}$, $60 \mathrm{~s}$ at $60{ }^{\circ} \mathrm{C}$ and $60 \mathrm{~s}$ at $72{ }^{\circ} \mathrm{C}$ and final elongation at $72{ }^{\circ} \mathrm{C}$ for $10 \mathrm{~min}$. PCR products were visualised on $1 \%$ agarose gel stained with ethidium bromide and their size was determined using molecular marker (100 bp). The products were then purified and sequenced using a BigDye Terminator v3.1 Cycle Sequencing Kit (Applied Biosystems, USA).

\section{Phylogenetic analysis}

Consensus sequences generated from raw trace files belonging to forward and reverse primers were made using SeqMan v.7.1.0 in the DNASTAR lasergene core suite software (DNASTAR Inc., Madison, WI, USA). In BLAST search, consensus sequences were used as queries for finding high similar subjects in GenBank database hosted by NCBI. Subjects with highest similarity were downloaded and aligned with sequences generated in this study with the Muscle software implemented in MEGA 6 (Tamura et al., 2013). Aligned sequences were manually checked when it was necessary. Phylogenetic analysis was performed using the neighbor-joining method implemented in MEGA 6. Bootstrap analysis was performed with 1000 replicates. Correspond to each dataset appropriate out-groups were selected.

\section{Results}

\section{Sampling and isolates}

During sampling process, 40 sites including parks, gardens and streets were inspected across Tabriz and the numbers of 30 infected samples were collected. Infected 
samples were obtained from elm trees showing wetwood symptoms such as outer sapwood and browning of the central core (Fig. 1a, b and c). During isolation process in the lab, from all infected samples collected, 92 isolates were recovered.

\section{Hypersensitive reaction and pathogenicity tests}

In hypersensitive reaction (HR) test of 92 isolates obtained, the numbers of 32 isolates could induce necrotic wounds in inoculation site on tobacco leaves. After the artificial inoculation, separate from those 32 isolates on elm young branches, 10 isolates were positive for pathogenicity test. Between these isolates, four isolates (M1, M2, M3 and M4) had good symptom from wetting or soaking signs (Fig. 1d-g); so these isolates were selected for diagnosis. These four isolates (M1, M2, M3 and M4) belonged to Brevundimonas bullata (Fig. 1g), Paracoccus alcaliphilus (Fig. 1d), Luteimonas aestuarii strain (Fig. 1f), and P. marcusii (Fig. 1e), respectively. Furthermore, disease symptom was not seen on young branches in negative control (Fig. 1h). In pathogenicity test, the symptoms of wetwood disease were seen on branches after 40 days in refrigerator at $5{ }^{\circ} \mathrm{C}$. To comply Koch's postulate, inoculated bacteria were re-isolated and their physiological and biochemical characters were examined. Based on our knowledge, these results concluded that each of the four isolates (M1, M2, M3 and M4) alone can cause and induce wetwood symptom. Thereby, even one isolate (or one species) from these four species can cause wetwood disease, too.

\section{Biochemical tests}

Biochemical tests were done using four isolates (M1, M2, M3 and M4) which were selected based on colony color and being pathogenic on young branches of elm tree. Based on biochemical tests, all examined bacterial isolates were Gram-negative bacteria. The results of other biochemical tests are presented in Table 1.

\section{Table 1}

Biochemical tests

\begin{tabular}{lcccc}
\hline Tests & M1 & M2 & M3 & M4 \\
\hline D-mannitol & - & + & - & + \\
Lactose & - & - & - & + \\
Maltose & - & - & + & + \\
Sucrose & - & - & - & + \\
Catalase & - & + & + & + \\
Oxidase & + & + & Negative & + \\
Gram & Negative & + & + & + \\
Citrate & + & + & Negative \\
\hline
\end{tabular}

+ and - present positive and negative reactions. M1: Brevundimonas bullata; M2: Paracoccus alcaliphilus; M3: Luteimonas aestuarii; M4: P. marcusii 

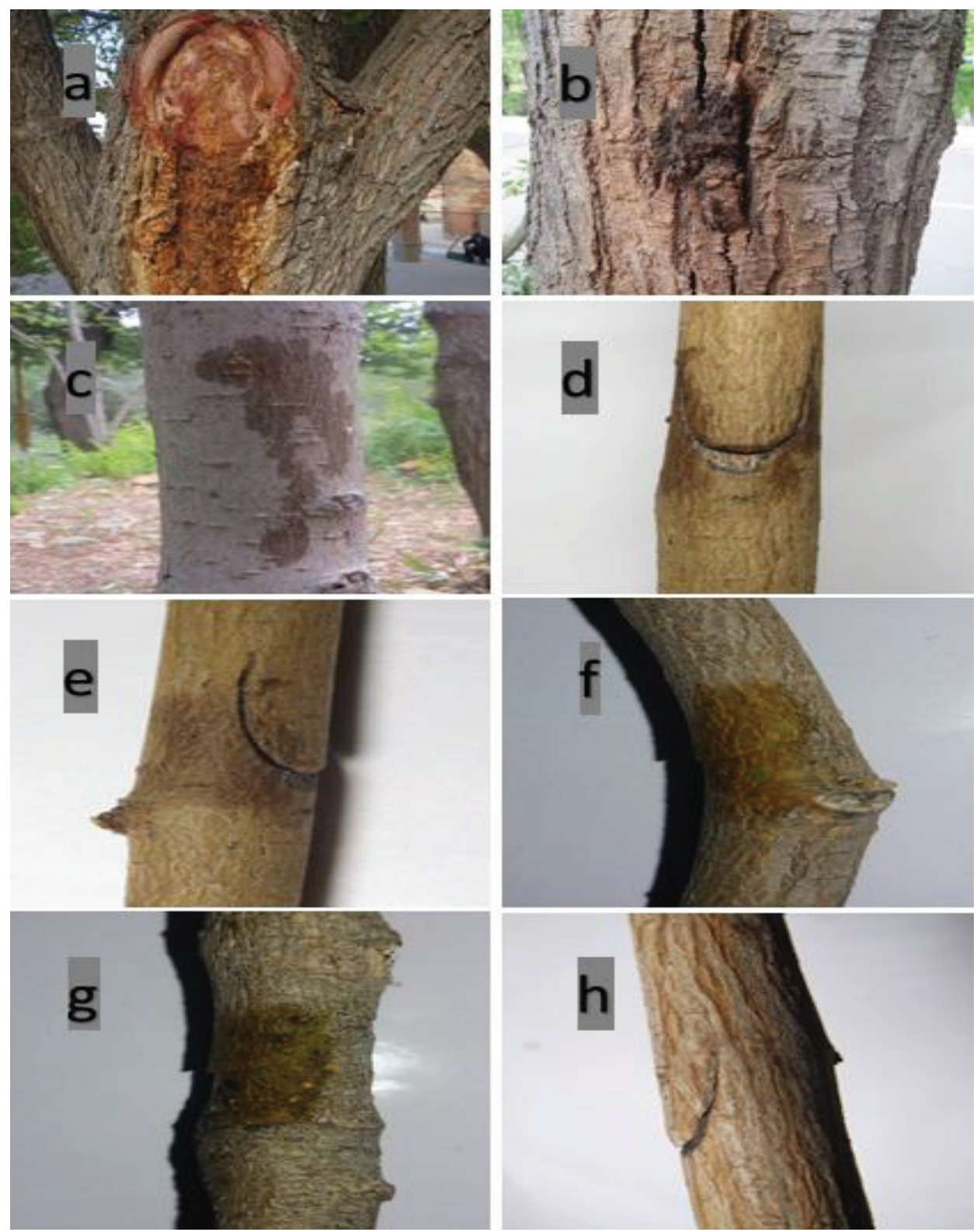

Fig. 1. a-c; Wetwood symptom (wetting and soaking of bark with ooze production) on naturally infected elm tree. $\mathrm{d}-\mathrm{g}$; Wetwood symptom (wetting and soaking of bark) on elm young branches after inoculation separately with single bacterial suspension, with four strains of Paracoccus alcaliphilus strain M2 (d), P. marcusii strain M4 (e), Luteimonas aestuarii strain M3 (f) and Brevundimonas bullata strain M1 (g), respectively. h; Negative control (without wetting and soaking of bark) 


\section{Phylogenetic analysis}

In PCR assay, a 1300 bp 16s rDNA fragment was amplified using the universal primers 27F/1492R for each studied isolate. After sequencing, consensus sequences generated in this study in BLAST search exhibited high similarity (99\%) with 16s-rDNA sequences of different species of Brevundimonas, Paracoccus and Luteimonas genera. During phylogenetic analysis, for each three datasets of Brevundimonas, Paracoccus and Luteimonas, three taxa including Caulobacter fusiformis (AB014894), Escherichia coli (X80725) and Rhodobacter capsulatus (D16428) were served as out-group, respectively. Based on neighbor-joining analysis and phylogeny inferred using the sequence data $16 \mathrm{~s}$ rDNA, the identity of four isolates selected including M1, M2, M4 and M3 in phylogeny analysis were determined as Brevundimonas bullata (accession Nos KX856926), Paracoccus alcaliphilus (accession Nos KX865104), P. marcusi (accession Nos KX889922) and Luteimonas aestuarii (accession Nos KX881920), respectively, with highest bootstrap support (Figs 2, 3 and 4).

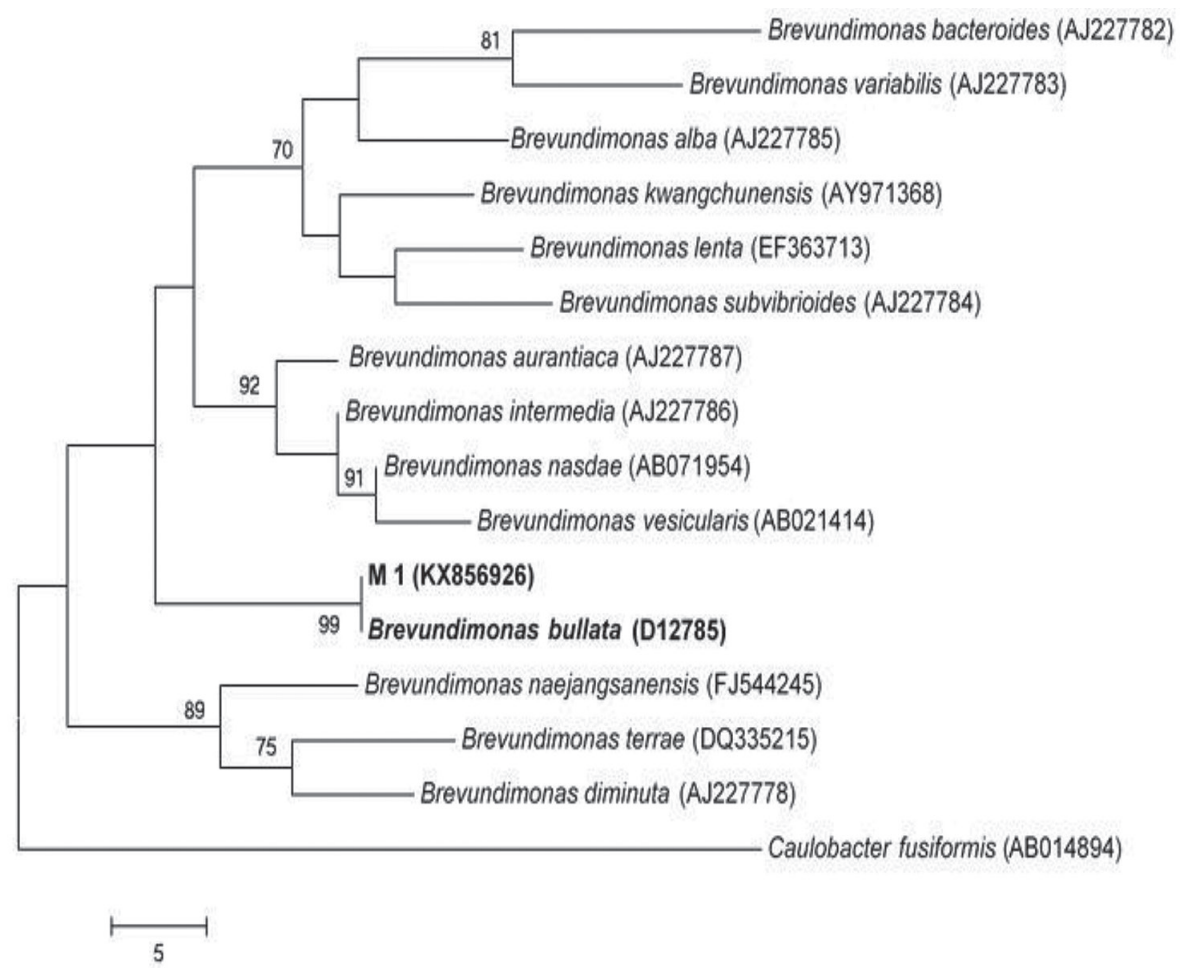

Fig. 2. The phylogenetic analysis of Brevundimonas spp. based on 16s rDNA gene sequences performed by neighbor-joining method. Bootstrap values ( $\geq 50 \%$ ) are indicated in the branch nodes based on 1000 replications. Accession numbers of reference strain are in parentheses that were obtained from Genbank.

Caulobacter fusiformis (AB014894) was used as an out-group. The scale indicates the number of substitutions per 100 nucleotides 


\section{Discussion}

Taking into account the increasing relevance of elm trees as landscape trees, this study aimed to characterise the bacterial associated with wetwood disease observed on elm trees which are mainly grown in gardens and urban parks across the Tabriz city. In this study, a combination of pathogenicity, biochemical and molecular characteristics revealed the identity of the bacterial isolates associated with wetwood disease on elm trees to be B. bullata, P. alcaliphilus, P. marcusii and L. aestuarii. Besides Luteimonas aestuarii that has been previously isolated from Ajuga bracteosa as root-associated bacterium (Kumar et al., 2012), there is no previous information on the pathogenicity of these bacterial on other plant species. Therefore, in current study using HR and pathogenicity tests was for the first time revealed that these bacterial species can be considered as potential pathogens on elm trees, particularly on host plants affected by environmental stresses.

Although, wetwood disease was initially thought to be caused by L. nimipressuralis as the sole etiologic agent of the disease (Carter, 1945) further studies reveled that various bacterial species, such as Enterobacter cloacae, Enterobacter agglomerans, Klebsiella oxytoca, Serratia fonticola, Bacillus megaterium, Pseudomonas fluorescens, Streptococcus mitis, Pseudomonas spp., Staphylococcus spp. and Acinetobacter spp., may be in association with wetwood disease (Ward and Zeikus, 1980; Murdoch and Campana, 1983). Accordingly, in this study various bacterial species belonging to different bacterial genera were shown to be involved in wetwood occurrence on elm trees. Several bacteria, including species of Enterobacter, Klebsiella, Pseudomonas, Serratia, Staphylococcus and Acinetobacter have previously been noticed causing wetwood disease on elm trees but it has not been conclusively demonstrated as the causal agents of the disease although they are directly involved (Murdoch and Campana, 1983; Jacobi, 2013). Generally, the most bacteria species isolated from wetwood are normally categorized as saprophyte or opportunistic pathogens (Murdoch and Campana, 1983). Since these bacteria are commonly found in both water and soil, they can be spread by absorption through wounds on roots, pruning cuts and wood-boring insects (Henn, 2004) and also due to presence of sugars and other nutrients into exterior sap oozed from infected trees, airborne yeasts, filamentous fungi and bacteria are usually attracted to it (Hartman, 2000). In contrary, in this study among the total of 92 isolates obtained, the numbers of 32 and 10 isolates showed HR and virulent activity on tobacco leaves and young branches of elm trees, respectively. These results show that bacterial pathogens can corelate directly with wetwood occurrence on elm trees (Murdoch and Campana, 1983), but disease incidence in nature probably occurs most often on the trees suffering wounds or environmental stresses (Ward, 1972). Therefore, this highlights the need to adopt appropriate sanitation principles to reduce the development of the disease.

Since most bacterial species isolated and identified in this study were isolated from the same wounds on the elm trees, it is assumed that wetwood disease on elm trees across the Tabriz city is caused by a number of $B$. bullata, P. alcaliphilus, $P$. marcusii and L. aestuarii species of bacterial pathogens. This complex relationship leads to synergistic effect on the pathogenicity mechanisms expression which subsequently increases the 
development of the disease. Some studies have shown that a complex of pathogens are involved in disease occurrence. For example, the activity of a complex of bacterial species including Pseudomonas cichorii, $P$. corrugata, $P$. viridiflava, $P$. mediterranea, $P$. fluorescens, Pectobacterium carotovorum, Pe. atrosepticum, Dickeya chrysanthemi in tomato

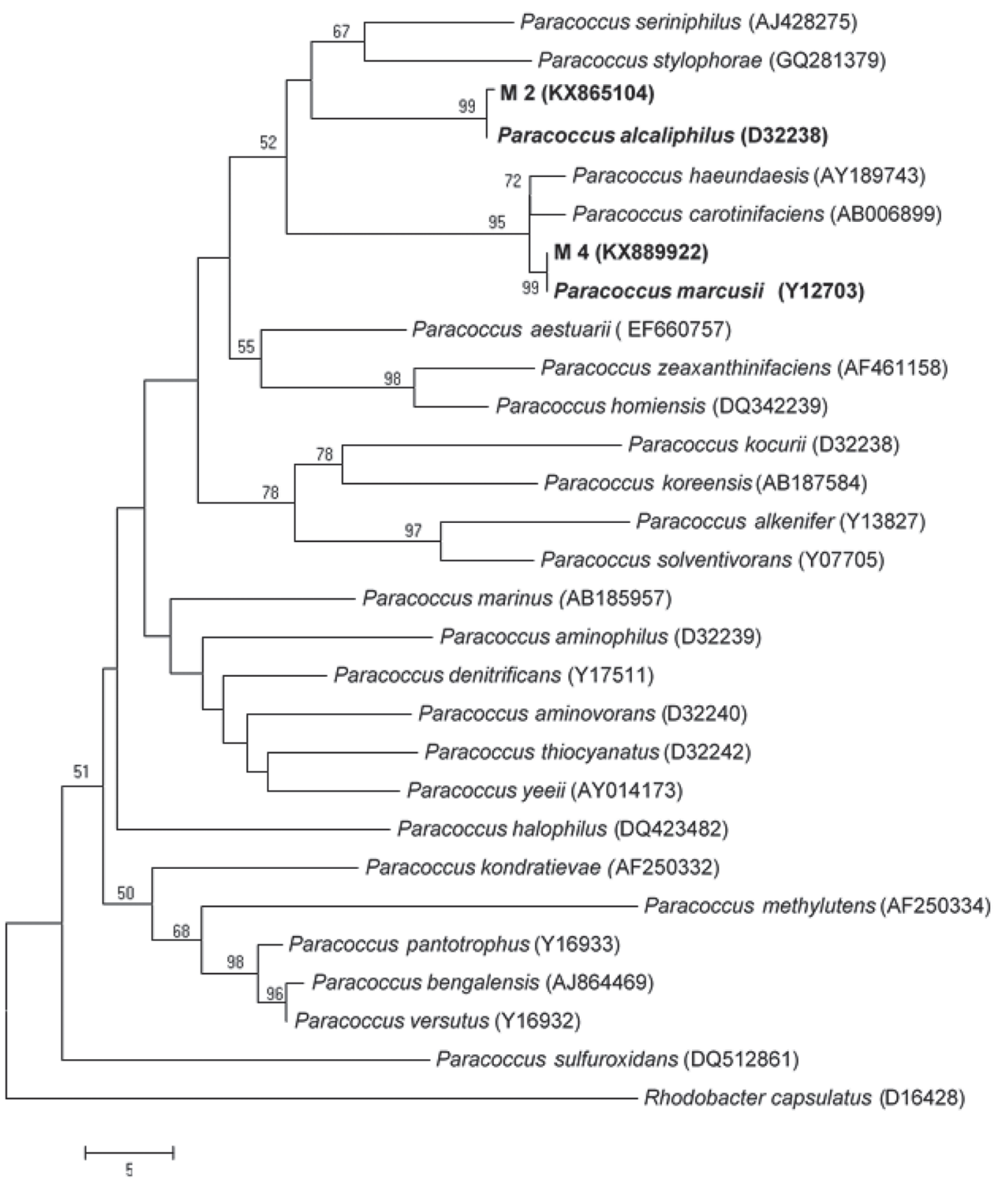

Fig. 3. The phylogenetic analysis of Paracoccus spp. based on 16s rDNA gene sequences performed by neighbor-joining method. Bootstrap values $(\geq 50 \%)$ are idicated in the branch nodes based on 1000 replications. Accession numbers of reference strain are in parentheses that were obtained from Genbank. Rhodobacter capsulatus (D16428) was used as an out-group. The scale indicates the number of substitutions per 100 nucleotides 


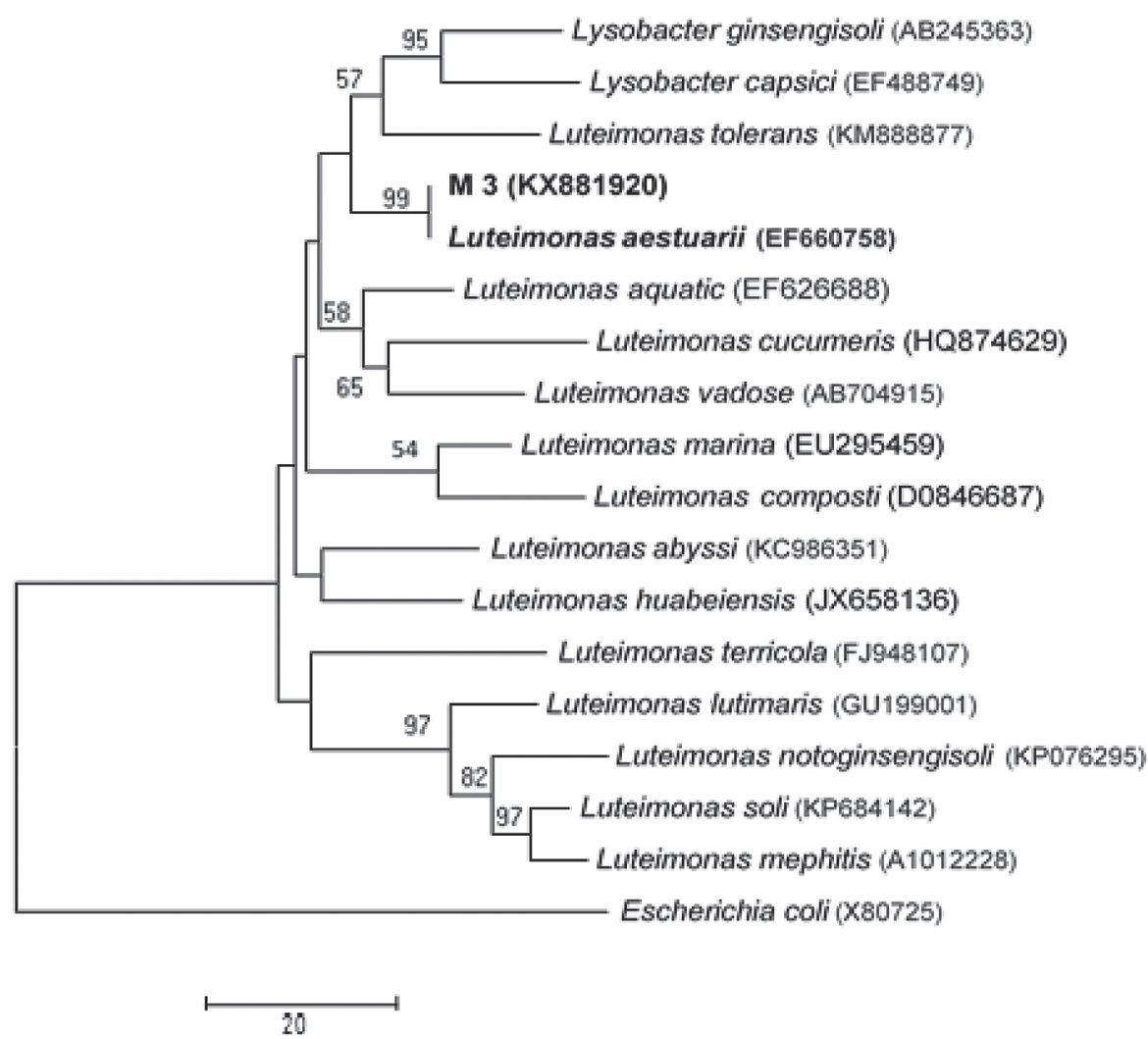

Fig. 4. The phylogenetic analysis of Luteimonas spp. based on 16s rDNA gene sequences performed by neighbor-joining method. Bootstrap values $(\geq 50 \%)$ are idicated in the branch nodes based on 1000 replications. Accession numbers of reference strain are in parentheses that were obtained from Genbank. Escherichia coli (X80725) was used as an out-group. The scale indicates the number of substitutions per 100 nucleotides

pith necrosis and P. fluorescens, P. marginalis, Pe. carotovorum in bacterial soft or head rot of broccoli has been demonstrated (Lamichhane and Venturi, 2015).

To the best of our knowledge, four bacterial species of B. bullata, P. alcaliphilus, $P$. marcusii and L. aestuarii reported here are in correlation of wetwood disease on elm trees for the first time in the world. Given the likely fast spread of the bacterial pathogens associated with wetwood disease by insects and mechanical tools, adoption of promising control methods such as the reaction of different genotypes against disease in combination with other appropriate ways in order to achieve disease management are suggested.

\section{Acknowledgement}

The authors would like to appreciate the Research Deputy of Tabriz University for financial support. 


\section{Literature}

Arabi, F., Nikravesh, Z., Babaeizad, V., Rezaeian, V. and Rahimian, H. (2006): Occurrence of bacterial leaf spot and blight of garden beet caused by Pseudomonas syringae pv. aptata in Iran. Iranian J. Plant Pathology $42,4$.

Carter, C. J. (1945): Wetwood of elms. Illinois Natural History Survey Bulletin; v. 023, no. 04.

Hartman, J. (2000): Bacterial wetwood and slime flux is different from winter pruning sap flow. Kentucky Pest News 872, 1-4.

Henn, A. (2004): Bacterial wetwood and alcoholic flux. Mississippi State University Extension Service Information Sheet 1664. 2 p.

Iraqi, M. M., Rahnama, K., Mostafa, M. and Marandi, M. (2008): Investigation on isolates of fungus the causal agent of Dutch elm disease in some areas of Golestan province and their pathogenesis effect on Ulmus species. J. Agr. Sci. Tech. 15, 186-194.

Jacobi, W. R. (2013): Bacterial wetwood. Colorado State University Extension Service Information. Gardening Series. Sheet 2. 910.

Khodaygan, P., Sedaghati, E. and Sherafati, F. (2011): Isolation of Enterobacter nimipressuralis associated with bacterial wetwood from elm (Ulmus spp.) in Rafsanjan. Iranian J. Plant Pathology 47, 481-482.

Kumar, G., Kanaujia, N. and Bafana, A. (2012): Functional and phylogenetic diversity of root-associated bacteria of Ajuga bracteosa in Kangra valley. Microbiological Research 167, 220-225.

Lamichhane, J. R. and Venturi, V. (2015): Synergisms between microbial pathogens in plant disease complexes: A growing trend. Frontiers in Plant Science 6, 385.

Moretti, C., Silvestri, F. M., Rossini, E., Natalini, G. and Buonaurio, R. (2007): A protocol for rapid identification of Brenneria nigrifluens among bacteria isolated from bark cankers in Persian walnut plants. J. Plant Pathology 89, 211-218.

Murdoch, C. W. and Campana, R. G. (1983): Bacterial species associated with wetwood of elm. Phytopathology 73, 1270-1273.

Roberts, D. V. (2011): Bacterial wetwood and slime flux. Michigan State University Extension Service Information, $14 \mathrm{p}$.

Roos, I. M. and Hatting, M. J. (1986): Bacterial canker of sweet cherry in South African. Phythopathology 18, 1-4.

Santini, A., Fagnani, A., Ferrini, F. and Mittempergher, L. (2002): San Zanobi' and 'Plinio'elm trees. HortScience 37, 1139-1141.

Schaad, N. W. (2001): Laboratory Guide for Identification of Plant Pathogenic Bacteria. $2^{\text {nd }}$ ed. APS Press, St. Paul. Minn., 409 p.

Scortichini, M., Belisario, I. A. and Motta, E. (1991): Bacterial species in relation to forest tree decline. J. Arboriculture 17, 246-249.

Stipes, R. J. and Campana, R. J. (1981): Compendium of elm diseases. American Phytopathol. Soc., 96 p.

Tamura, K., Stecher, G., Peterson, D., Filipski A. and Kumar, S. (2013): MEGA6: Molecular Evolutionary Genetics Analysis version 6.0. Mol. Biol. Evol. 30, 2725-2729.

Thomidis, T., Tsipouridis, C., Exadaktylou, E. and Drogoudi, P. (2005): Note: Comparison of three laboratory methods to evaluate the pathogenicity and virulence of ten Pseudomonas syringae pv. syringae strains on apple, pear, cherry and peach trees. Phytoparasitica 33, 137-140.

Ward, J. C. (1972): Anaerobic bacteria associated with honeycomb and ring failure in red and black oak lumber. Phytopathology 62, 796.

Ward, J. C. and Zeikus, J. G. (1980): Bacteriological, chemical and physical properties of wetwood in living trees. In: J. Bauch (ed.): Natural Variations of Wood Properties. Mitteilungen der Bundesforschungsanstalt fuer Forst und Holzwirtschaft Hamburg, Nr 131. Max Wiedebusch, Hamburg, Germany, pp. 133-166.

Weisburg, W. G., Barns, S. M., Pelletier, D. A. and Lane, D. J. (1991): 16S ribosomal DNA amplification for phylogenetic study. J. Bacteriol. 173, 697-703. 
